\title{
Examination on the Effect of the Psychomotor Training Program on Certain Basic Motoric Properties in 20-Year-Old Men
}

\author{
Milaim Berisha \\ Sakarya University, \\ Sakarya, Turkey
}

\author{
NigarYaman \\ Bratin University, \\ Bartın, Turkey
}

\author{
Ayşe Önal, ÇetinYaman \\ Sakarya University, \\ Sakarya, Turkey
}

\begin{abstract}
This study has been conducted to examine the effect of the psychomotor training program planned by the researchers on the coordination, agility and balance in 20 -year-old young men. The training was implemented for 45 minutes twice a week during 8 weeks. The study has been conducted on in total 52 20-year-old voluntary male students who study at the Department of Physical Education and Sports Teaching, Faculty of Sports Sciences at Sakarya University and do not have any acute or chronic disease which might hinder the tests to be done. They were divided equally into two groups to form the experimental group and the control group. The pre-tests results and post-tests results obtained after 8-week psychomotor trainings of the certain basic motor skills (coordination, agility and balance) were assessed. The differences between the results of the pre-test and post-test conducted on the experimental group and the control group were examined to identify the effect of the psychomotor training on the coordination, agility and balance skills. As a consequence, it was observed that 8-week (psychomotor) training comprising exercises in varied directions, varied paces, varied forces, not accustomed positions and changing pace and speed affected the balance $(p<0.05)$, agility $(p<0.05)$ and coordination $(p<0.05)$ positively.
\end{abstract}

Keywords: psychomotor training, motor skills, mental skills, physical education and sports

\section{Introduction}

Psychomotor training is formed when the motoric actions are performed at the same time and in varied directions and paces, in combination and conducted successively in varied forces (Rintala, Pienimäki, Ahonen, Cantell, \& Kooistra, 1998).

In psychomotor training, actions performed in coordination, balance and agility are formed with, for instance, combining multiple actions such as walking and running, climbing, balance movements, jumping and turning, passing under, over and around the barriers in varied directions and paces. It is known that combining multiple actions requires the psychological factors such as quick decision making, linking complex actions, being creative in unusual circumstances and choosing the most rational solution to be at high level along with the high motoric skills (Rintala et al., 1998).

Psychomotor training enables mental, psychological and motoric processes, muscle coordinative and

Milaim Berisha, Ph.D. student, Sakarya University.

NigarYaman, Assistant Prof., Bartin University.

Ayşe Önal, Ph.D. student, Sakarya University.

ÇetinYaman, Associate Prof., Sakarya University. 
balance actions to develop. In addition, psychomotor training enhances complex sportive techniques implemented in coordination, agility and balance in most of sports branches. Psychomotor development is the body and mind's gaining mobility in parallel with the bodily growth and development of central nervous system (Child development and education-psychomotor development, 2013). It is known that the training type which improves parameters like agility, coordination, strength, and balance and response rate is the psychomotor training. Coordination skill is believed to be one of the significant motoric factors in formation of individual sports series as it enables the adaptation between the muscles used to perform two or more actions together and the central nervous system, and unites the strength, endurance, speed, flexibility and balance parameters taking part in the tactics of several sport branches and collective sport branches. Franklin claims that coordination skill enables sports technique implementations to improve (Franklin, 2004).

Agility increases the performance of the athletes through changing direction, deceleration and acceleration, etc. by using the all motoric, anthropometric and psychological parameters. Notwithstanding, it was defined as the ability of acting, stopping and changing direction quickly by Acklandand et al. (Applied anatomy and biomechanics in sport, 1994).

Balance assures all biomotoric factors and sense parameters to be used by keeping body at a stable position in perceptual frame of gravity center or enabling determined actions towards the external forces. It also assures the locomotoric system to function statically and dynamically and in harmony. It is acknowledged that balance, as a biomotoric skill, is associated with the parameters such as sight, sense and somatotoni (Soyuer \& Mirza, 2006). In the light of this information, coordination, agility and balance skills are vital factors in formation of action series and techniques of several sports branches by ensuring strength, endurance, speed and all parameters participated in the action to be connected accordantly and to be performed at the same time, to be accelerated and decelerated. Accordingly, coordination, agility and balance are not only motoric but also psychological parameters and it is known these factors are related to psychomotor training (Oswald, Rupprecht, Gunzelmann, \& Tritt, 1996).

As coordination, agility and balance are considered crucial motoric (decision making quickly, connecting complex actions, being creative in not accustomed circumstances and choosing the most rational solution, etc.) and psychological factors, they are seen elements to be examined and brought forward a proposal in this study and considered worthy to be studied.

In literature review, it was discovered studies similar to our study and method. The psychomotor training program implemented in the studies of Rintala, Pienimaki, Ahonen, Cantell, and Kooistra (1998) were divided into 3 dimensions. These are: general motoric actions, ball skills (actions done with a ball) and actions performed in unusual circumstances. The training included walking and running by changing direction and speed, climbing, jumping on trampoline, rhythmic jump, jump rope, dynamic equilibrium, jumping towards a target, jumping on a ball, turning and passing under barriers after jumping and were called "psychomotor" training (Rintala et al., 1998). Sheppard and Young (2006) put forth that the factors such as direction and position changing speed of the body or lower and upper extremities, flexibility, running, take off, static and dynamic equilibrium were infrastructure of agility, balance and coordination (Sheppard \& Young, 2006).

This study has been conducted to examine the effect of the psychomotor training program which was implemented for 45 minutes twice a week for 8 weeks on the coordination, agility and balance in 20 -year-old young men. 


\section{Method}

\section{Research Design}

In this study, the model with pretest-posttest control group out of the experimental methods was used and the study has an experimental qualification.

In this study, the experimental design was used and the differences between the results of the pre-test and post-test conducted on the experimental group and the control group were examined to identify the effect of the psychomotor training implemented for 45 minutes twice a week for 8 weeks on the coordination, agility and balance skills.

8-week training program that included running, jumping, changing direction, balanced positions and rolls was performed twice a week for 45 minutes in order to improve the agility, balance and coordination features of the participants. The training program comprised walking in balance, shuttle run pliometric movements, passing under and over the barriers, changing directions while running, standing in the glider position and forward and backward rolls.

\section{The Sample}

52 voluntary male students $(1.75 \mathrm{~m}, 73 \mathrm{~kg}$, and 20-year-old), who study at the Department of Physical Education and Sports Teaching at Sakarya University and do not have any acute or chronic disease which might hinder the tests to be done were participated into the study. They were divided equally into two groups to form the experimental group (26 students) and the control group (26 students).

\section{The Agility Test}

Two cones are placed in a decussated way in the corners of $12 \mathrm{~m} \times 12 \mathrm{~m}$ gymnastics ground. The participant gets prepared in front of the cone which is in the starting position as he starts to a serial. When the participant is ready, he runs fast towards the other cone placed diagonally, decelerate his speed, touch the 6-inch cone and return. Participant does it 5 times and completes the test at the opposite corner. It is started to keep time as the participant lifts up their feet. When any part of the participant crosses the line (the line placed vertically on the ground), the chronometer is stopped and time is kept. The measurement is done in split second (Mark D. Sleeper, Lisa K. Kenyon, \& Ellen Casey, 2012).

\section{Flamingo Balance Test (to Be Able to Stand in Balance on One Foot on a Beam)}

The participant stands in balance as long as he can on his preferred leg on a balance. The participant bends his leg backward, hold it with his hand and stand on one foot like a flamingo. The participant can hold the forearm of the assistant in order to adjust this balance. As the participant unclasps the arm, the test begins. In that case, participant is to keep that balance for 1 minute. The test is stopped whenever the balance is lost. For instance, when participant unclasps his leg or any part of his body touches the ground, it is considered the balance is lost. After every stopover, the same process is implemented and continues till standing in balance for 1 minute is accomplished. The established point is displayed at the charts.

Material: $45 \mathrm{~cm}$ long, $5 \mathrm{~cm}$ high and $4 \mathrm{~cm}$ wide wooden or metal beam. Two $15 \mathrm{~cm}$ long, $4 \mathrm{~cm}$ wide supports to provide stabilization. A similar flamingo balance test was used in the study "The effect of volleyball training on the physical fitness of high school students" of Sozen (2012). A similar test was also used at a single-stage judo test instruction (Single-stage judo test instruction, 2015). 


\section{Coordination}

Forward and backward roll: participant is required to do forward and backward rolls. Passing over barriers: Participant passes under the first $50 \mathrm{~cm}$ high barrier and over the second one. If it is not done properly, it is redone. Walking on a balance beam: Participant steps on the reference line and runs or walks on the balance beam and goes down. He has to step on the finishing line. If participant falls down, he restarts from where he falls. Jumping 5 times to the right and left on two legs on a barriers: Participant jumps successively 5 times over $40 \mathrm{~cm}$ high and $20 \mathrm{~cm}$ wide barriers on two feet without knocking over them. If participant knocks over the barrier, he sets the barrier and continues. Carrying medicine ball: Participant carries three medicine balls one by one from the box they are placed to the other box which is placed $5 \mathrm{~m}$ away in parallel. Slalom: Participant crosses diagonally between the slalom bars. Sprint $(10 \mathrm{~m}): 10 \mathrm{~m}$ running is done and time elapsed in these stations is recorded through a chronometer. Scoring: The best performance gets 40 points. Participants are given points by reducing 2 points at each degree. A similar coordination test was conducted at a single-stage judo test instruction (Single-stage judo test instruction, 2015).

\section{Data Analysis}

The statistical analyses were conducted via SPSS 22. General Linear Model, Multivariate (MANOVA) analysis was used to identify the differences between the test results of the experimental group and the control group which were conducted to identify the effect of the 8-week psychomotor training implemented for 45 minutes twice a week on the coordination, agility and balance skills in 20 -years-old men.

\section{Findings}

The differences between the pre-test and post-test results of the students.

Table 1

The Differences Between the Pre-Test and Post-Test Results of the Experimental Group

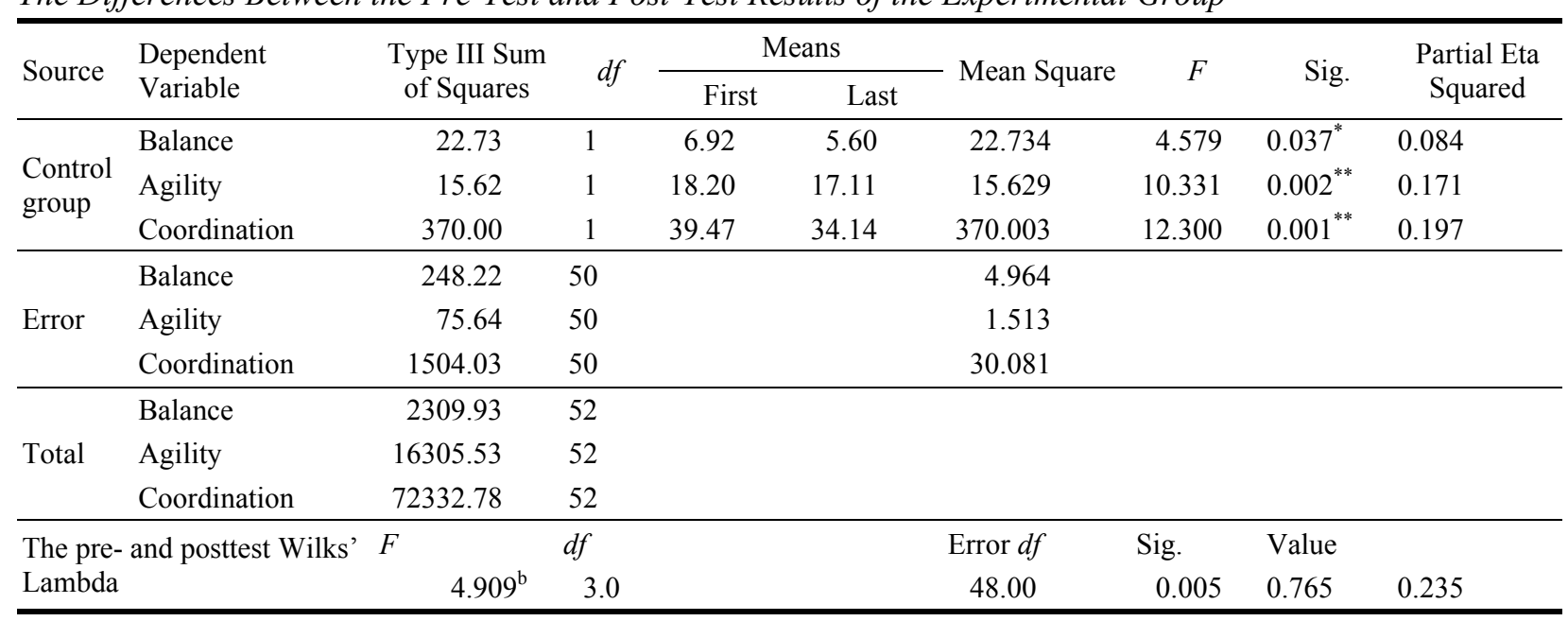

Note. ${ }^{* *} p<0.00,{ }^{*} p<0.05$.

As the Table 1, Wilk's $\lambda=0.765, F(3,48)=4.90, p=0.005$, partial $\eta^{2}=0.235$, was examined, it was observed statistically significant differences between the balance pre- and post-test results of the experimental group $F(1,50)=4.579, p=0.037$, partial $\eta^{2}=0.084,(\bar{x}=6.92),(\bar{x}=5.60)$.

Statistically significant differences were identified between the agility pre- and post-test results of the 
experimental group $F(1,50)=10.331, p=0.002$, partial $\eta^{2}=0.171,(\bar{x}=18.20),(\bar{x}=17.11)$.

Similarly, it was determined statistically significant differences between the coordination pre- and post-test results of the experimental group $F(1,50)=12.300, p=0.001$, partial $\eta^{2}=0.197,(\bar{x}=39.47),(\bar{x}=34.14)$.

Table 2

The Differences Between the Pre-Test and Post-Test Results of the Control Group

\begin{tabular}{|c|c|c|c|c|c|c|c|c|c|}
\hline \multirow{2}{*}{ Source } & \multirow{2}{*}{$\begin{array}{l}\text { Dependent } \\
\text { Variable }\end{array}$} & \multirow{2}{*}{$\begin{array}{l}\text { Type III Sum } \\
\text { of Squares }\end{array}$} & \multirow{2}{*}{$d f$} & \multicolumn{2}{|c|}{ Means } & \multirow{2}{*}{ - Mean Square } & \multirow{2}{*}{$F$} & \multirow{2}{*}{ Sig. } & \multirow{2}{*}{$\begin{array}{c}\text { Partial Eta } \\
\text { Squared }\end{array}$} \\
\hline & & & & First & Last & & & & \\
\hline \multirow{3}{*}{$\begin{array}{l}\text { Control } \\
\text { group }\end{array}$} & Balance & 5.87 & 1 & 7.26 & 6.59 & 5.870 & 0.692 & 0.410 & 0.014 \\
\hline & Agility & 0.21 & 1 & 17.23 & 17.36 & 0.213 & 0.539 & 0.466 & 0.011 \\
\hline & Coordination & 11.78 & 1 & 37.94 & 36.99 & 11.780 & 1.951 & 0.169 & 0.038 \\
\hline \multirow{3}{*}{ Error } & Balance & 424.30 & 50 & & & 8.486 & & & \\
\hline & Agility & 19.69 & 50 & & & 0.394 & & & \\
\hline & Coordination & 301.97 & 50 & & & 6.039 & & & \\
\hline \multirow{3}{*}{ Total } & Balance & 2929.81 & 52 & & & & & & \\
\hline & Agility & 15577.44 & 52 & & & & & & \\
\hline & Coordination & 73308.85 & 52 & & & & & & \\
\hline \multicolumn{2}{|c|}{$\begin{array}{l}\text { The pre-and posttest Wilks' } \\
\text { Lambda }\end{array}$} & $F$ & $d f$ & & & Error $d f$ & Sig. & Value & 0081 \\
\hline
\end{tabular}

Note. ${ }^{* *} p<0.00,{ }^{*} p<0.05$.

When Table 2, Wilk's $\lambda=0.916, F(3,48)=1.46, p=0.236$, partial $\eta^{2}=0.084$. , was examined, it was not observed any statistically significant differences between the balance pre- and post-test results of the control group $F(1,50)=0.692, p=0.410$, partial $\eta^{2}=0.014,(\bar{x}=7.26),(\bar{x}=6.59)$.

Any statistically significant differences were not determined between the agility pre- and post-test results of the control group $F(1,50)=0.539, p=0.466$, partial $\eta^{2}=0.011,(\bar{x}=17.23),(\bar{x}=17.36)$.

It was not identified any statistically significant differences between the coordination pre- and post- test results of the control group $F(1,50)=1.951, p=0.169$, partial $\eta^{2}=0.038,(\bar{x}=37.94),(\bar{x}=36.99)$.

\section{Discussion}

This study has been conducted to examine the effect of the psychomotor training program which was implemented for 45 minutes twice a week for 8 weeks on the coordination, agility and balance in 20 -year-old young men.

With reference to our findings, psychomotor actions performed in varied directions, paces and forces improve not only the motor development of the athletes but also their actions associated with the cognitive skills such as mental balance, agility and coordination (Bompa \& Haff, 2015). In order to clarify this, an 8 -week psychomotor training program was conducted on 52 voluntary male students who study at the Department of Physical Education and Sports Teaching at Sakarya University for 45 minutes twice a week. The findings are as follows:

In the balance test, it was identified statistically significant differences between the pre $(\bar{x}=6.92)$ and post $(\bar{x}=5.60)$ test results in the group who did training $(p<0.05)$. In the control group, it was not determined any statistically significant difference between the pre $(\bar{x}=7.26)$ and post $(\bar{x}=6.59)$ test results $(p>0.05)$. As the psychomotor training includes actions done in varied directions, paces and forces, it is thought that 
keeping the body in balance by changing direction, pace, speed and position improves balance of the participants. Similarly, in another study, it was observed that improvement of balance skill was done through psychomotor trainings and correlated with the motor skills like walking, running, jumping, climbing, acceleration, etc. (Hazar \& Taşmektepligil, 2008; Psychomotor development, 2007).

In the agility test, it was observed statistically significant differences between the pre $(\bar{x}=18.20)$ and post $(\bar{x}=17.11)$ test results in the group who did training $(p<0.05)$. In the control group, it was not determined any statistically significant difference between the pre $(\bar{x}=17.23)$ and post $(\bar{x}=17.36)$ test results $(p>0.05)$. It is believed that performing various and complex actions simultaneously or successively affects reaction and action time positively by enabling individuals to feel mentally alert. Thus, individuals change their direction and speed more quickly (Bompa \& Haff, 2015; Hazar \& Taşmektepligil, 2008). It was observed that circuit training constituted with repetitive take off, climbing, running, push off and pull was effective in motor development (Bompa \& Haff, 2015; Günay, Tamer, \& Cicioğlu, 2013).

In the coordination test, it was determined statistically significant differences between the pre $(\bar{x}=39.47)$ and post $(\bar{x}=34.14)$ test results in the group who did training $(p<0.05)$. In the control group, it was not identified any statistically significant difference between the pre $(\bar{x}=37.94)$ and post $(\bar{x}=36.99)$ test results $(p>0.05)$. It was confirmed that coordination was required between the sports techniques in order that multiple techniques, tactic and various series could be implemented in different sports branches. Furthermore, it was determined that motor skills were required to be at high levels in order to keep coordination at high level (Bompa, 2011; Mengütay, 1998). For instance, the actions performed successively such as doing series formed with various actions in gymnastics, applying tactics in football, implementing techniques in ski, etc. are done by athlete's creating images in the brain. Accordingly, it was observed that improvement of coordination was accomplished through not only strength, endurance and speed (motoric) training but also changing direction and speed, doing exercises in not accustomed positions, changing pace and speed, performing several actions simultaneously, exercising multiple body parts (sports thinking or sports intelligence) (Bompa, 2011). Similar findings were obtained in the study "The SIMA-project: Effects of 1 year cognitive and psychomotor training on cognitive abilities of the elderly" of Oswald et al. (1996). It was stated that coordination skill was associated with psychomotor training and its improvement was enabled through psychomotor training (Oswald et al., 1996). In this regard, it has been examined the effect of the psychomotor training program which was implemented for 45 minutes twice a week for 8 weeks on the coordination, agility and balance in $(20 \pm 6$ years old) young men in our study. The findings were given above and conclusion and recommendations were given below.

\section{Conclusion and Recommendation}

Consequently, it has been observed that 8-week psychomotor training implemented in varied directions, pace and forces affects balance, agility and coordination improvement positively.

It has been seen that exercise of passing to balance position from not accustomed position and trying to set up new position is done in order to improve balance.

Performing varied or not accustomed actions constantly improves the reaction time of athletes (Günay et al., 2013). Accordingly, agility skill is improved by changing direction and speed and increasing acceleration.

It has been observed that it is required strength, endurance and speed (motoric) training, changing direction and speed, doing exercises in not accustomed positions, changing pace and speed, performing several 
actions simultaneously, exercising multiple body parts (sports thinking or sports intelligence) in improvement of coordination.

As not accustomed, complex actions, linking multiple actions performed in varied pace and direction, standing in varied positions are the features of balance, agility and coordination skills, balance, agility and coordination skills and intelligence are results of thinking flexibly and quickly. Coordination skill is defined as "Sports Thinking or Sports Intelligence" by Bompa (2011).

According to our findings, in order to improve motoric and psychological factors; any sports branch from which top form and success is expected and required:

To improve strength, reaction and action time; it is recommended that actions (running, jumping, pushing off, pulling, etc.) are performed from backward to forward and vice versa, from up to bottom and vice versa fluently and athlete should memorize the actions.

The content of trainings has to be changed regularly; thus, brain is prevented from getting accustomed to the routine by doing new actions. It is acknowledged that brain is enabled to be exercised more by the improvement of mental factors through sports. Thus, athletes can perform the most complex and difficult actions.

It is recommended station and race track trainings to be implemented in individual and collective sports.

The psychomotor training used in that study may be adapted to the trainings of other sports branches by enriching its content and thus physical performance and Sports Thinking or Sports Intelligence of athletes may be improved by enabling their body and brain to exercise more.

\section{References}

Ackland, R., Elliott, B., \& Bloomfield, J. (Eds.). (1994). Applied anatomy and biomechanics in sport (Vol. 2). Blackwell Scientific Publications.

Bompa, T., \& Haff, G. (2015). Dönemleme, Antrenman kuramı ve yönetimi (T. Bağırgan, Trans. 5. baskı ed.). Ankara: Spor yayın evi ve kitap evi.

Bompa, T. O. (2011). "Dönemleme” Antrenman kuramı ve yöntemi (T. Bağırgan, Trans. 4. baskı ed.). Ankara Spor yanın evi ve kitab evi.

Çocuk gelişimi ve eğitimi psikomotor gelişim. (2013). Ankara Milli eğitim bakanliği. Retrieved from http://www.megep.meb.gov.tr/mte_program_modul/moduller_pdf/Psiko-Motor\%20Geli\%C5\%9Fim.pdf.

Franklin, E. (2004). Conditioning for dance. Human Kinetics, 1, 248.

Günay, M., Tamer, K., \& Cicioğlu, İ. (2013). Spor fizyolojisi ve performans ölçümü (3. bask1 ed.). Ankara: Gazi Kitabevi.

Hazar, F., \& Taşmektepligil, Y. (2008). Puberte öncesİ dönemde denge ve esnekliğin çeviklik üzerine etkilerinin incelenmesi. SPORMETRE Beden Eğitimi ve Spor Bilimleri Dergisi, VI(1), 9-12.

Mark D. Sleeper, M., Lisa K. Kenyon, L., \& Ellen Casey, E. (2012). Measuring fitness in female gymnasts: The gymnastics functional measurement tool. The International Journal of Sports Physical Therapy, 7(2), 124-138.

Mengütay, S. (1998). Artistik Cimnastik, Temel teknik hareketlerin ögretim yöntemleri ve yardım şekilleri (2. bask1 ed.). Ankara: TUTIBBAY Ltd. Şti.

Oswald, W. D., Rupprecht, R., Gunzelmann, T., \& Tritt, K. (1996). The SIMA-project: Effects of 1 year cognitive and psychomotor training on cognitive abilities of the elderly. Behavioural Brain Research, 78(1), 67-72.

Psikomotor gelişim (2007). Ankara: Milli Eğitim Bakanlığı $\quad$ Retrieved from http:/hbogm.meb.gov.tr/modulerprogramlar/kursprogramlari/cocukgelisim/moduller/psikomotorgelisim.pdf.

Rintala, P., Pienimäki, K., Ahonen, T., Cantell, M., \& Kooistra, L. (1998). The effects of a psychomotor training programme on motor skill development in children with developmental language disorders. Human Movement Science, 17(4), 721-737.

Sheppard, J., \& Young, W. (2006). Agility literature review: Classifications, training and testing. Journal of Sports Sciences, 24(9), 919-932. doi:10.1080/02640410500457109 
Soyuer, F., \& Mirza, M. (2006). Relationship between lower extremity muscle strength and balance in multiple sclerosis. Journal of Neurological Sciences, 23(4), 257-263.

Sozen, H. (2012). The effect of volleyball training on the physical fitness of high school students. Procedia-Social and Behavioral Sciences, 46, 1455-1460.

Tek aşamali judo sinav talImati. (2015). Türkiye: Türkiye Judo Federasyonu. Retrieved from https://sporegitim.sgm.gov.tr/dokuman/JUDO.pdf 